\title{
Export Restrictions, Tax Incentives and the National Artistic Patrimony
}

Trinity Economic Paper Series

Paper No.2000/6

JEL Classification : $\mathrm{H} 20$ and $\mathrm{H} 40$

\author{
Clare McAndrew and John O'Hagan \\ Department of Economics \\ Trinity College \\ Dublin 2
}

email: mcandrec@tcd.ie and johagan@tcd.ie

\begin{abstract}
This paper analyses the main forms of government intervention used in the UK to protect the national artistic patrimony. It examines the two most common policy measures used in the art market: export regulation and tax incentives and reports their use over an 8 year period from 1990 to 1998. It also reviews the UK's collective obligations to patrimony internationally and specifically as a member of the European Union.
\end{abstract}




\section{Introduction}

Protection of the national artistic patrimony is a recurrent theme in discussions in Europe regarding trade in art. Much of the artistic patrimony in most western countries, including the UK, is in state ownership; there is however also a significant amount of patrimony works in private hands and it is these items that are subject to state intervention in an attempt to retain them within national boundaries. The two most common forms of such intervention in the UK, export regulation and tax incentives, are the subject matter of this discussion.

Broadly speaking, the national patrimony includes moveable and immovable heritage items (land, buildings and monuments). Within the category of moveable patrimony there is a need to further distinguish between items of 'art' and 'non-art'. For example certain old books, zoological specimens, engineering instruments, cars and armoury can be prevented from export on the grounds that they are part of a county's patrimony. The discussion in this paper primarily focuses on moveable art objects, i.e. paintings, sculpture and similar items; there is though a certain degree of blurring between the boundaries of art/non-art and movables/immovables. Only moveable objects of course are in effect subject to export regulation and art objects are likely to be by far the most valuable and therefore most sought-after of the moveable heritage objects.

In the UK, as in most other countries, there is an attempt made to try to limit the number of art works that are subject to restrictions on trade through use of criteria such as age or value limits. The UK is the centre of the international art trade in Europe and as such has tried to define as narrowly as possible the range of items subject to regulation. Licensing-application requirements only apply to works of art over 50 years old and then generally only if over a value ranging between $£ 6000$ $£ 39,600$ depending on the category (see Table 1). To be prevented from export on patrimony grounds, such works must also fulfil the strict Waverley criteria which judge their importance both artistically and to the nation. Similarly, to avail of the patrimony-tax exemptions strict criteria are applied including that the work must be pre-eminent in its category. Therefore, although it is difficult to put a precise definition on what is the national artistic patrimony, as no system of listing is currently in place, it can be said that the concept applies to a narrow range of old and valuable works of art of significant artistic and national importance. 
This paper analyses the main forms of government intervention used in the UK to protect the national artistic patrimony and is structured as follows. The first section describes export regulations and analyses their importance in UK art trade. The second looks at tax incentives specifically directed towards domestic retention of heritage assets, and the final section reviews the UK's collective obligations to patrimony internationally and in particular as a member state of the European Union.

\section{Export Regulation in the UK}

Regulation of exports of works of art from the UK differ according to their destination: exports to non-EU states are governed both by EU law and UK law and interstate exports by UK laws only. An EU licence is required for the export of works of art from the UK (or any member state) to a third-country destination for works of art valued at or above the specified EU licence limit. A UK licence is needed for exports out of the Community of works valued above the UK limit but below that of the EU as well as for trade within the EU of works valued at or above the relevant UK licence limit. (The details on categories of artefacts covered and threshold levels, in terms of age and value, are given in Table 1).

The primary UK legislation regarding exports of works of art comes from the 'Import, Export and Customs Powers (Defence) Act of 1939' which is implemented in practice by powers given to the Department of Industry and Trade under the 'Export of Goods (Control) Order of 1985'. This Act is the basis for government control of all UK exports and it was not until after the second world war that it was specifically applied to works of art. $^{1}$ As a general rule, under this legislation an application for an export licence is required if goods are over 50 years old at the date of export and over a certain reference value relevant to their particular category. Table 1 gives a summary of the major categories of cultural works covered by the legislation.

If an object is valued greater than these limits, an export licence must be sought from an expert advisor within the Department of National Heritage specialising in the particular art form; he/she grants the licence or recommends its refusal. In the latter instance, the application is referred to the 'Reviewing Committee' which must judge on the basis of the same pre-specified criteria whether 
the licence should be granted or further steps taken. These criteria are known as the Waverley criteria and were established in 1952 by the Waverley Committee. The three tests applied to determine if the object is of sufficient national importance to delay or deny export are:

1. Is the object so closely connected with the nation's history and current life that its departure would mean a misfortune for the nation?

2. Is it of outstanding artistic and aesthetic importance?

Is it of outstanding significance for the study of some particular branch of history, art, or learning? ${ }^{2}$

If the decision is made that the object does sufficiently meet the criteria, the export licence is not refused outright but a delay period is given generally of between two to six months to allow an offer from the state, a domestic institution or public body to come forward. It is an important feature of UK law that the right of the Committee to deny an export licence is not absolute and can only be upheld if a bona fide offer is forthcoming from a state or public collection within the specified delay period, otherwise the licence must be granted. A concern in the setting up of a licensing system is that it should not penalise owners and potential exporters by unfairly depressing prices by blocking access to international markets.

The UK system ensures this, because when a licence is refused the owner must be guaranteed a public offer to purchase the work at a 'fair market price' or price obtainable on the open international market. The 'fair price' is determined by relevant experts and the Committee but generally implies: if auctioned - the bid price + buyer's premium + dealer's commission; if private sale - contractual price + dealer's commission if applicable; if no transaction - valuation by independent valuer or expert advisor; d) the price does not include insurance, storage or interest costs of carrying the object whilst the export licence remains pending (see Polonsky and Canat, 1996).

If the delay period elapses and no offer is made, a licence must be granted. However, occasionally and in exceptional circumstances the period of licence suspension may be extended to allow time for national public bodies to raise 
necessary acquisition funds. The Department of National Heritage in 1994 stated that the period could be extended to 12 months but this extension must only be used for highly exceptional items and in rare circumstances.

A decision made in 1990 after the proposed sale of Canova's The Three Graces to the J.P. Getty museum in California also amended legislation to allow both public and private offers to be considered, primarily from concerns over lack of national funding and high international prices offered for art. ${ }^{3}$ Finally and again very occasionally, the government can impose an 'indefinite stop' on an export licence. This occurs only where the applicant has refused a valid offer from a national source at the established fair price, in which case no further appeal will be heard for ten years after the initial application unless the applicant can prove a change in circumstances or that the Waverley criteria no longer apply.

To reduce the need for applications for specific licences being put forward for every art export, the Department of National Heritage also operates a system of 'open individual export licences' and 'open general export licences' both of which allow export of items without a licence. The latter give blanket permission to certain items, even if over 50 years, to be exported and largely includes those exported under an EU licence or for objects which an EU export licence is not required.Open individual export licences are valid for specific authorised individuals and institutions and for four main categories:

- licences for goods imported less than 50 years ago;

- licences for regular exporters of manuscripts, documents, archives and photographs;

- licences for temporary (1-2 year) export of objects owned or under the care of museums;

- licences for certain other art objects approved by the $\mathrm{DNH}$, exported on a regular basis and if imported less than 50 years ago.

In reality the number of art objects requiring the application procedure represents only a small percentage of the total exports of art from the UK. Table 2 shows that in the eight-year period given, licensed exports were only a tiny fraction of total exports: less than two per cent of the total throughout. Generally of those exports that do require a licence application, cases that need to be referred to the 
Reviewing Committee are also small in number. Table 3 shows that in the same period, the total number of cases considered by the Reviewing Committee was 253 or an average of 28 per year. In 204 of these cases, export authorisation was deferred for a period and only 93 were not eventually exported due to a domestic offer for purchase.

Concern does remain however in the few isolated cases such as the proposed Three Graces sale that while the Waverley system works effectively in selecting appropriate national patrimony works to protect, lack of national funds may prevent proposed export controls working satisfactorily. ${ }^{4}$ Rights of pre-emption allow a delay period to try to raise funding, but export restriction in the UK can only be used if there are eventual funds available to buy objects considered to be national treasures and these funds are more difficult to raise when international art prices are high.

This issue has been addressed in recent years with the setting up of the Department of National Heritage in 1992 which funds the National Heritage Memorial Fund. A survey of the financial year 1993/1994 (see Casey et al, 1996) found that public, EU and private funding of the "visual arts" amounted to $£ 619$ million (of which $£ 286$ million came from the DNH) and of this total $£ 42.5$ million was specifically earmarked as assistance towards the purchase and acquisition of objects by museums and galleries. Since this survey year the National Lottery has also been established which gives 20 per cent of its net marginal revenue to the the National Heritage Memorial Fund for distribution to national heritage concerns. This source of funds provides financial assistance for the acquisition, maintenance or preservation of art works of outstanding importance to the UK national heritage. Polonsky and Canat (1996) estimated that Lottery funds as making available amounts of around $£ 5$ million per week or $£ 250$ million per annum. The Heritage Lottery Fund provides money directly to museums and galleries to purchase art works of artistic and historic interest and importance on the condition that they also raise part of the funding themselves or from other public or private sources. By December 1997, over 390 awards had been given to national museums and galleries totalling over $£ 590$ million, while by the end of January 1998, 8892 million had also been donated specifically to heritage-based projects (DCMS, 1998). For the period from November 1994 to December 1998, the Heritage Lottery Fund contributed £1,118million to 2,270 heritage projects, in other words approximately $£ 279$ million per year 
This substantial influx of funding combined with the significant amounts available from public, private and European sources should mean that sufficient funds are available to match the asking market prices for any of the exceptional items that the Waverley system seeks to retain domestically. In 1998 the Reviewing Committee saw 26 objects, recommending that most have licences deferred and 12 have already been successfully acquired by British institutions (DCMS, 1999).

Finally, the most recent addition to the UK's export laws in this regard is the reforms introduced in March 1997 by the Department of National Heritage as outlined in its paper 'Export Licensing for Cultural Goods'. According to Bailey (1997), the paper primarily deals with the issue of purchase of works that have been exportstopped or deferred. The legislation imposes new conditions in the so-called 'Ridley Rules', that is the rules surrounding private purchases of export-deferred works. Under the new laws, domestic private buyers will be required to sign an agreement with a recognised and appropriate museum or gallery agreeing to provide both reasonable public access to the object, satisfactory conditions and surroundings for conservation and a promise that they will not sell for a specified period to ensure that public access is secured. Although these conditions are a positive move towards ensuring public access, they make it less attractive for private buyers to step in and put an offer on an export-deferred work. The full effect of this new change in the legislation in practice remains to be seen. ${ }^{6}$

\section{Tax Policy and the National Patrimony}

Tax incentives are used by most governments as a means to support the arts. Tax incentives are designed with three main objectives in mind: to channel funds towards artists and art institutions; to encourage domestic retention of art and discourage exports through encouraging donations to domestic museums or making it more financially attractive to hold the object rather than sell it abroad; and to offer relief in return for public access and/or ownership by domestic arts institutions.

The UK has introduced several fiscal measures to support the cultural sector both generally through the waiving of taxes for donations to art-related institutions 
and through more specific measures directed at preserving national patrimony art within the UK. The main tax breaks offered relating to art are that of the charitable contributions deductions from individual or company income tax as well as the British deed of covenant system. These are general provisions towards charitable giving and relate to a variety of art forms including contemporary art. There are also in place specific tax incentives aimed directly at preserving nationally important works of art within the UK. These provisions mainly concern capital tax deductions for donations and bequests toward the National Heritage and are intended to account for superior prices on international markets, versus those available in the UK, by providing additional fiscal incentives to retain art works domestically.

In the UK, transfers of titles between private individuals are subject to capital gains tax, and transfer and inheritance tax, either at the time of transfer for donations or death for successions. However, the "Taxation of Charitable Gains Act" (1992) makes available three forms of tax relief aimed at the above mentioned national heritage goals which will be discussed in the following paragraphs.

\section{A: Private Treaty Sale Provision}

When works are sold, full capital gains tax along with any previously conditionallyexempt inheritance taxes (see later) are due. These tax charges are often substantial and the final net amount received by the seller significantly less than the sales proceeds. However, under the Private Treaty Sale (PTS) provision, an object can be sold to certain listed institutions in Schedule Three of the Inheritance Tax Act 1984 and the taxes due avoided. ${ }^{7}$ This is a rather broad incentive as the item does not have to be pre-eminent or of national importance; the only condition that must apply is that an aforementioned institution is interested in purchase. The system is beneficial to both the purchasing institution and seller due to the method of price determination. The acquisition price for the institution is determined by first subtracting the tax due from the normal price the item would obtain on the open market and then 25 per cent of the total tax saving is added to determine the final purchase price. This additional 25 per cent is called a 'doucer', literally a 'sweetener', as it sweetens the purchase price offered to the seller and the acquiring institution also gains through an improved purchase price over that available on the open market. 
For example, assume someone wishes to sell a work of art which is valued at $£ 100,000$ and on which there will be capital gains tax due of 40 per cent as well as previously conditionally-exempt inheritance tax of 20 per cent. In an ordinary open market sale the seller would receive $£ 40,000$ ( $£ 100,000$ less $£ 60,000$ ). However under the PTS provision, this sum is increased by 25 per cent of the tax saving and hence the sales price $=£ 40,000+£ 15,000(25$ per cent of $£ 60,000)=£ 55,000$. Hence, both have gained and both share the value of the tax exemption - the seller obtains an extra $£ 15,000$ and the museum saves $£ 45,000$ off the acquisition price (bought at $£ 55,000$ rather than $£ 100,000$ ). This must of course be set against the fact that the Inland Revenue has to write off $£ 60,000$ worth of forgone tax and hence the opportunity cost to the taxpayer of those funds.

The amounts of tax forgone in Private Treaty Sales are not reported separately in the Inland Revenues annual statistics. In a 1993/94 report, the National Heritage Memorial Fund reported private treaty sales accounted for as little as $£ 1.7$ million. This could however be a significant underrepresentation of the total as only a relatively small percent of such sales are assisted by NHMF funds (Casey et al, 1996).

Some problems do arise in practice in the working of Private Treaty Sales system. First, establishing an accurate price base or market value can be difficult. Second, the extent of the douceur is flexible up to 25 per cent and debates over its level and fixity are recurrent; for low-valued items, 25 per cent may not provide sufficient inducement to sell under PTS and for high-value items it might not be necessary to offer as much. Finally, museums may still be unable to afford the reduced purchase price $(£ 55,000)$ and works may still be lost to higher-bidding international buyers.

\section{B: Acceptance in Lieu}

If inheritance tax or capital transfer tax are due on an asset or estate, donations of certain works of art to the state is a mechanism that allows taxpayers discharge their tax debt. If approved by the Secretary of State of National Heritage, works of art can be given in lieu of taxes on estates and properties within them due on transfer and the object itself is also tax exempt 
The value (V) or implicit price of the work is calculated in the same manner as for PTS $(\mathrm{V}=\mathrm{P} \text { less tax }+25 \text { per cent douceur })^{8}$ which is a relatively attractive deal for the donors as again the price may be better than that available on art markets, less taxes, and they may have the added advantage of recommending where the object is placed. Occasionally it will be allowed to remain in situ or be passed on privately in which case it is legally state owned and effectively out on loan. Most commonly however it is actually transferred to the Inland Revenue and institutions will bid for it with the Heritage Minister deciding to which it will be sold.

Again, the state gets to keep the work in the UK and at an acquisition price less than that on open markets. But in this case the Inland Revenue has a significant cost in that no tax is paid on the transfer of the object; in addition, a percentage of the value is offset against other estate and property taxes. Because of this fact, the state is more choosy about what items it will accept in lieu of taxes - to be considered they must be both museum-worthy and pre-eminent in its own right or as an addition to a collection

Guidelines developed by the Office of Arts and Libraries in classifying objects as pre-eminent are:

- Does the object chosen have a particularly close association with our history and national life? (which includes foreign works);

- Is the object of especial artistic or art-historic interest?;

- Is the object of especial importance for the study of some particular form of art learning or history?;

- Does the object have an especially close association with a particular historic setting? (Inland Revenue, 1986).

Once advice has been given by relevant experts and the Museums and Galleries Commission, the final decision-making is carried out by the Inland Revenue along with Heritage Ministers - usually the Secretary of State for National Heritage or the Minister of Arts. ${ }^{9}$

Until the mid-1980s, a major problem with the scheme was the ceiling or limit placed on what could be accepted in lieu. The Department of National Heritage budget allocated for reimbursing the Inland Revenue was kept at two million pounds. This changed in July 1985; provision was granted for access to a 'contingency fund' 
for large important items taken from the Public Expenditure Reserve (often between $£ 10$ - 12 million). ${ }^{10}$

Despite these early problems, coupled with some administrative difficulties, this incentive now makes up a significant part of the value of the works acquired by the state. There have also been suggestions to extend the incentive to allow tax credits that can be set against future tax liabilities when the value of important items, or especially collections, exceeds the tax to be satisfied. Table 4 shows a sample of the amounts of taxes satisfied by the acceptance in lieu scheme in the period 1990-98 and how in practice this exemption only accounts for a very small amount in consideration of the volume of overall trade in art in the UK.

\section{C: Conditional Exemptions}

This tax incentive, the most financially important of the three, provides 'conditional exemption' from inheritance taxes, capital transfer taxes, capital gains taxes and estate duties for those acquiring art by gift or inheritance. To avail of these exemptions, certain conditions must be fulfilled.

1. The work must be considered by the state to be of national artistic, historic or scientific interest (generally heritage works deemed of outstanding importance). ${ }^{11}$ The 1998 Finance Act introduced the additional criteria that such interest should be of a pre-eminent nature meaning that the object or group of objects concerned would make a pre-eminent addition to a national, local authority, university or an independent museum (Capital Taxes Office, 1999). The test used in the legislation is the same as those provisions on acceptance of heritage assets in lieu of tax liabilities, decided by the Inland Revenue in light of advice from the Museums and Galleries Commission. (Items exempted under these new rules concerning preeminent quality however are not automatically accepted in satisfaction of taxes and this decision remains at the discretion of the Secretary of State.)

2. It must also be deemed of sufficiently high quality to be displayed in a public collection or be 'museum worthy.'

3. The owner must agree to keep the object permanently in the UK (unless given special permission by the Capital Taxes Office for temporary export for exhibition purposes). 
4. They must also agree to take reasonable steps to preserve and maintain the object and ensure reasonable access for the public either through allowing access in situ in private homes or through loan to a public institution for exhibition for at least 28 days of the year (subject to negotiation). Alternatively, under the 1992 legislation, details of the item and its whereabouts could be maintained at a National Art Library in the Victoria and Albert Museum or Public Records Office where the public may consult records and must be allowed viewing by appointment or, alternatively, be lent on request for temporary exhibition for not more than six months in a two-year period. Changes introduced by the 1998 Act mean that there must be a measure of public access without prior appointment or 'open access' under terms agreed with the Capital Taxes Office the extent of which will vary depending on the nature and type of the asset, and its preservation and maintenance needs. A fee may be charged in most circumstances, provided it is in keeping with the owner's statutory obligations to provide 'reasonable access' (i.e. a charge reasonable to the public at large).

The conditional exemption can be maintained if the work is donated to someone else and the new owner fulfils the same conditions (or to tax exempt collections, museums, etc.). However if the object is sold publicly, the exemptions are revoked and full, including back taxes, are due. Owners are requested to give the Museums and Galleries Commission three months warning of intended sales to allow UK public institutions attempt to match the offer. Although this is not written into law, sellers can be sanctioned for non-compliance through export regulation - including placing indefinite stops on national important items.

Not all applications will be accepted; for example, in the period 1986-1992, 49 per cent of the 545 applications had been accepted at the end of the period (Selwood et al, 1996). The reason for such a low number of applications could be due to the complexity of the system which limits access to those relatively knowledgeable about both art and the tax system as the only ones who can use it effectively. Also terms of exemption will expire year to year which, combined with variations in mortality rates and changing the levels of inheritance due, causes significant fluctuations in how much exemption this system ends up delivering year to year. Table 5 gives some 
examples of both the variation between years and the relatively considerable importance of the exemption.

\section{International Obligations}

As a member of the European Union and of the international trading community generally, the UK art market is becoming increasingly subject to international legislation governing various aspects of its activities including exports of art, taxes, and restitution of works stolen or illegally exported from their country of origin. The main emphasis of the international agreements is on the last mentioned and this will be the focus of this section of the paper.

\section{A: EU Regulations}

Free trade in all goods within the internal market is a guiding principle of the EU, guaranteed under Articles 9 and 30-34 EC of the Treaty of Rome. It was recognised alongside this however the need to reconcile free movement with that of legitimately protecting member states cultural and artistic heritage. Works of art were therefore given special status exempting them from free trade. For intra- EU trade, Article 36 EC provides a derogation from 30-34, allowing member states to adopt or maintain prohibitions, restrictions or measures of equivalent effect on the import, export, or transit within the EU of national treasures having artistic, historic or archaeological value. This exception also applies to third-country exports, that does not conflict with GATT, which makes similar reference, and provisions in Article 20 (European Commission, 1998)

Each member state can define their own national treasures (using their own form and scale of values) and then adopt any suitable action to protect them due to the needs arising from the abolition of internal frontiers. The idea behind the legislation was that the formation of the Single Market meant the removal of checks and controls at internal frontiers (regardless of product) which might encourage illicit trade or make it more difficult to prevent the export of cultural goods. In a Single Market it would be more physically easy to illegally (or legally) remove national treasures to other member states and offer them for export to third countries which could lead to the depletion of both an individual nation's patrimony and that of the EU as a whole. 
The Commission therefore included Article 36 in view of reconciling free trade in goods with rights to protect national and Community patrimony. In practice, this last remaining exception to the free trade postulate of the EU has led to considerable segmentation of the EU art market.

For extra-EU trade, two further measures were adopted into EU law in 1992 and 1993 and hence binding in the UK namely:

1. Council Regulation No. 3911/92 regarding the export of cultural goods to third countries;

2. Council Directive $93 / 7$ on the return of unlawfully removed cultural objects.

Both are aimed at 'supplementing' divergent national rules with a common system of protection at a Community level in line with the EU principle of subsidiarity.

The first regulation requires that an EU export licence be obtained on top of any licensing requirements in national laws if a cultural good is to be exported outside the EU (see earlier). The regulation covers archaeological items and books over 100 years old and any painting, print, sculpture, drawing or mosaic over 50 years old (and not belonging to the author) or over a certain threshold value for its category (European Commission, 1992). The regulation was adopted to act as a minimum standard to ensure that once internal borders were abolished, states with the most lenient export policies would not become an open door to third countries, but under Article 36 each state retains the right to adopt tighter restrictions and take a wider view of what it considers to be its national patrimony. The legislation has tended to have little effect on restricting UK trade due to their liberal system of export control (see earlier and Table 1). On an EU-wide level it has however led to the continuation of widely divergent interpretations resulting in two conflicting trends in elucidation of the term 'National Treasure':

- an 'extensive' interpretation: by countries largely in the south which export cultural goods and have a rich and sought-after heritage. They aim to enforce tight restrictions through broad definitions ( e.g. Italy, Spain, France).

- a 'restrictive' interpretation: by importing countries like the UK, which tend to be poorer in terms of national heritage and often where the major art markets are located. They advocate loose regulation or restrictions on a imited number of items. 
Biondi (1997) states that the correct interpretation of National Treasures should not refer to the generality of all art or cultural goods, but to a specific category that forms an indissoluble link with the cultural heritage of a particular nation. In correctly interpreting Article 36, the status of a National Treasure should not be judged on the fame or notoriety of the work or artist (although it should be of outstanding artistic importance to qualify) but specifically of the importance of its links to a nation's culture and history. In assessing the value of an art treasure to the national patrimony, most countries impose their own 'closest connection' test, such as the Waverley criteria in the UK, and often may try to avoid complex issues of attribution. Criteria used attempt to pinpoint works that should be protected; however, many remain subjective and give rise to difficulties in achieving uniformity in the absence of some established community-wide standards. As such, the problems of definition largely remain and have made application of the Regulation difficult and legislation often varied and inadequate - resulting again in a segmented European art market.

Directive 93/7 aims to achieve 'minimal harmonisation' by providing a mechanism for the return of cultural goods unlawfully removed from a member state. Under this directive the government of a state from which the article has been removed can bring an action for its return in the courts of the state in which it currently resides. The directive only applies to cultural objects removed after 1 January 1993 and must be national treasures of artistic, historic or archaeological value, belong to one of the categories listed in the directive or be listed on the inventory of a national public collection. Objects that are in the UK, which would spark such proceedings had they not been taken pre- 1993 include the Greek governments request for restitution of the Elgin marbles and the Egyptians request for the Rosetta Stone. Whatever the outcome of debates over the merits or otherwise of restitution, the impact of the enforcement of this legislation could be seen as threatening to the patrimony of the UK with these and other pieces of foreign origin residing in some of the most important national collections. However, despite recognition of its potential value in reducing unlawful trade, the directive has still not been implemented in certain states, namely Greece, Austria, Germany and Italy due to conflicting legal arguments between nations regarding bona fide possession, ownership rights, rules of private law, foreign public law exceptions and so on. As 
success of this return system relies on substantial co-operation between national authorities, non-implementation has limited its effects in practice. $^{12}$ There was significant opposition from various sectors of the British art trade before the directive was implemented in the UK, as they feared it would hamper trade and create administrative burdens and buyer uncertainties. In practice, the effects of it implementation are difficult to assess as it has as not yet generated any return proceedings.

\section{B: Other International Regulations}

The UK has been subject to an increasing number of efforts between groups of countries internationally to regulate trade in art. Co-operation has often been part of regulating trade generally such as clauses found in GATT or the Treaty of Rome which cover art objects within the range of tradable commodities. Other international agreements have been designed specifically to deal with trading art and other cultural objects, whether formalised as legal obligations between countries or via advisory and exhortatory agreements which may equally bring significant pressure for compliance.

Like EU Directive 93/7, many international agreements deal with issues surrounding the prevention of theft and return of stolen items of art. Art works, like all forms of property, have rights attached to ownership for return proceedings through the law if stolen. It may be asked therefore why they are the matter of special regional and international agreements as opposed to the normal policing and legal arrangements for example for stolen cars. One of the most significant reasons for this special treatment of national patrimony works, besides the fact they generally involve huge sums of money, is that these items unlike cars and other valuable items are unique and irreplaceable both in their own right and in terms of their cultural links to a nation.

Some of the UK 's more important international obligations include:

- Commonwealth: the Commonwealth, like the EU, is an example of an important trans-regional arrangement designed to promote trade and co-operation generally and therefore affects trade in art. The Scheme for the Protection of Material Cultural Heritage within the Commonwealth has been in place since 1993 and gives broad 
guidelines on areas such as unlawful export and import, and seizure and recovery, whilst allowing members to impose other specific controls where they see fit.

- International Non- governmental Organisations: there are several examples of nongovernmental international organisations that have no legal powers in members jurisdiction but still exert considerable pressure to conform to their objectives and policies. An important example, involving many national UK museums, is ICOM which has a large international membership and promotes ethical acquisition policies. Although it cannot stem the flow of illicit objects into private hands, its 'moral' influence on museums, which collectively make up the largest market for works of art, is often regarded as more significant than specific legal restrictions. IOPA is another example of such an organisation whose aims are to deal with offences against art, including theft, illicit traffic, and forgery. It runs a database of art which catalogues data on the work, its identifying characteristics and ownership details to aid recovery and restitution.

-UNESCO: perhaps the most important international arrangement regarding art and its protection has come from the work of UNESCO formalised in the 1970 UNESCO Convention on the Means of Prohibiting and Preventing the Illicit Import, Export and Transfer of Ownership. It is the major international instrument in this area, not only due to its coverage, with 86 current signatories which include the two major art markets of the UK and the US, but also due to the fact that it provides reciprocal and binding obligations rather than simply recommendations. The main impetus for the document came from the idea in many countries that the protection of art could only be effective if organised both nationally and internationally amongst states working in close co-operation. The document itself is substantial and had a long and complex drafting history ${ }^{13}$

After the introductory articles defining cultural property, national patrimony and statements of opposition to illicit traffic, the most substantive provisions are in Articles 7 and 9. Article 7 deals with the prohibition of the import of stolen cultural property (within the boundaries of national legislation) as well as procedures for recovery and return. Article 9 calls for multilateral action if a nation's patrimony or important category of art is in 'serious jeopardy' from pillaging and illicit transfer. 
The Convention represents a serious international effort at protecting artistic heritage; however, many states remain reluctant to enforce the export laws of other states regarding what they can import. Also, as with all large and expansive pieces of legislation, it has to be questioned how much is merely on paper and how much is enforced and operative. Due to the wide range of attitudes involved (and some vague and indeterminate clauses), there remains conflicting views between signatories as to what the Convention requires of its members and which are the key provisions. This ambiguity has led to a lack of uniformity in implementation in areas, with countries such as the US and the UK often adopting a minimalist approach to their obligations (only applicable to stolen goods) whilst others such Australia and Canada use a more broad interpretation of the legislation. ${ }^{14}$

-UNIDROIT: from the origins of the UNESCO Convention, UNIDROIT, a 56member independent intergovernmental organisation devoted to examining ways to co-ordinate and harmonise laws between groups of states, also opened to signature in 1995 the Unidroit Convention on Stolen or Illegally Exported Cultural Objects. This convention, using similar clause and definitions to UNESCO, demands the mandatory return of any stolen cultural object if its removal has impaired its physical preservation, integrity, preservation of information (e.g. historical) or its traditional or ritual use or if it can be shown to be of significant cultural importance to the requesting state. The Convention again reflects a willingness on behalf of many important member states of the international art community to protect art and reduce illicit trade and includes signatories such as Switzerland, Netherlands, France and Italy. However, many countries including the UK have expressed reservations. The UK has still not signed, ratified or acceded to the convention, voicing a variety of concerns not least of which involves the legal difficulties in trying to harmonise the law in this area. For example, in trying to unify legislation relating to transfers of cultural objects, the differences in the laws relating to ownership rights and title are very different in the UK compared to signatory countries such as Italy, Portugal or France. Under UK law, the rights of the owner/seller are superior to those of the purchaser. If an item is purchased in good faith and is later found to be stolen it will be returned to its rightful owner without compulsory compensation to the purchaser. In continental European countries on the other hand, protection of the purchaser takes 
precedence and compensation is often due on restitution. Other objections from the UK art trade have concerned the wide and subjective definitions of cultural property, and in particular national treasures, which are open to a variety of interpretations depending on where the action for restitution is being taken.

\section{Conclusion}

Overall the UK's system for regulating the trade in art is a liberal one - in keeping with the predominant ideology which stresses the rights of private property and freemarket principles.

Regarding export control, the Waverley criteria are used to test the status of a piece of work which means government approval for export is only required for very valuable and important works and prohibition is extremely rare. The regulations are designed as selective export controls with specific and high value and age limits for licence requirements. From Tables 2 and 3 it is evident that licensed exports in fact make up only a tiny portion of total arts exports from the UK and even in the rare case that a licence is required for export, all denials and delays must be based on the strict interpretation of the Waverley criteria and cannot be absolute as export must be allowed if pre-emptive rights are not exercised. A similarly liberal export system is found in other major art markets such as Switzerland and the US; the latter has the most lenient system, with no legislation barring or limiting the export of art except very specific laws protecting Indian sacred sites. In contrast, many of the art-rich nations such as Italy or Greece have highly restrictive export control which can classify virtually any work of subjective interest to the state as an inalienable national treasure and embargo its export. In Italy for example over 30 million works are listed (Hughes, 1992) and require authorisation for export (which is rarely granted).

The three specific national heritage tax provisions outlined clearly focus on giving incentives to retain national patrimony art compared to often more general systems of tax relief in other countries. These incentives apply to a relatively narrow range of items and like the export regulation system, criteria are attached to the incentives in attempts to screen items and ensure that only the most important pieces are targeted. This specificity in offering incentives takes account of the fact that all tax relief is the use of public money and whilst the public purse will always be 
limited, the range of items that could be considered as part of the cultural heritage is potentially vast. By keeping eligible items to only the most important, the state is ensuring that the public is getting the 'best value' for the type of relief given.

Regarding the actual cost of these specific UK incentives, the Private Treaty Sale and conditional exemption are relatively low-cost mechanisms to domestically retain works when compared to the government actually having to face the price of buying works on the open market. Acceptance in lieu is arguably more costly to the sate; however, as noted, this incentive makes this tax expenditure explicit through an actual physical expenditure or budgetary transfer. That is, when an item is accepted in lieu, the relevant national heritage bodies actually make a payment to the Inland Revenue which helps to remind those involved that taxes do have direct financial costs and use in one area will always leave less to spend on others. As seen in Table, 4 however, in reality the scheme represents only a relatively tiny annual cost to the state.

Another important provision in tax incentives related to the arts concerns access and ownership status. An important premise in the UK tax law is that the state views that it is not necessarily desirable for works to belong to public institutions particularly given their limited funds for conservation and maintenance. The Board of Inland Revenue (1986) clearly state in their general policy statements for capital tax and national heritage that whilst their prime objective is the preservation and maintenance of national heritage for the benefit of the community, they have taken the view that, so far as possible, property of this kind should remain in private hands and its owners should be encouraged to retain and care for it whilst ensuring some form or access for public display. For example, with acceptance in lieu, ownership is transferred to the state but possession can be retained. With conditional exemptions, both ownership and possession are retained once certain criteria for public access or exhibition are fulfilled.

This emphasis on private ownership seems to be at odds to some degree with the objectives of tax incentives to broaden access to the greatest quantity of quality cultural heritage items. It could be argued that if the object needs to be classified as a 'national heritage item' to receive an incentive then it should be easily accessible to the 'national public'. The arguments given by the government however are that, where possible, items should be displayed in context and in keeping with its historical 
associations plus the fact that private owners are often more able to care for and maintain their own property especially in light of the complaints of museums of lack of funds. In the case of conditional exemptions, however, there are still valid criticisms. The system of merely listing objects at for example a national library and the strong emphasis on the protection of the security of the owner does arguably mean that access to the general public is hampered and that the system is really only applicable to the most knowledgeable of art scholars and historians who can use it effectively and know what to look for. The changes introduced in the 1998 Finance Act have tried to address these factors; for example, in enforcing a degree of open access and requirements for owners to publicise access and undertakings related to the item.

A problem that arises in the UK system, as with many others, is that of valuation of works for tax purposes. The question arises as to how can you arrive at an accurate market value for an object that you are shielding from the open market and its system of international valuation. For example, when a private treaty sale is to be undertaken, parties must try and establish some market price to base their calculations on as well as negotiate the extent of the douceur, while they are essentially removing the item from trading and the natural process of market evaluation on open markets. Schuster (1986) makes the argument that the availability of provisions such as these can end up harming the seller. Once these provisions are in place and it becomes known that a museum is interested in an item, this could dampen the interest of private individuals in bidding for the work. Such incentives could therefore actually injure the seller by reducing the price ultimately realised at auction whether or not the government uses it rights of pre-emption. It must be said, though, that this incentive does significantly reduce buyer uncertainty and as seen in the example given often turns out a more favourable price than that attainable after full tax liabilities on the open market.

Finally, increasing pressure from the international community to harmonise regulations and matters concerning restitution may be have a significant impact on the art trade in the UK and in particular that relating to the national patrimony. Despite the fact that the UK has never been a significant art producer, it maintains impressive national collections of patrimony art of which many pieces are of foreign origin. The 
future impact of restitution legislation could be potentially serious for these collections. 


\section{Endnotes}

${ }^{1}$ In 1949 a number of important art works were denied an export licence on the grounds that it would constitute a loss to the national artistic patrimony. This led to the setting up of the Waverley Committee formed to advise on policies adopted by the UK government to control the export of works of art and antiques of particular national historic or artistic interest or national treasures.

${ }^{2}$ Works denied export on this basis include:

Re 1) Kneelers Kit- Kat Club portraits and the Velasquez collection given to the Duke of Wellington by the King of Spain.

2) Elgin Marbles

3) Certain very rare art pieces have been denied export on this basis along with for example, rare books or technical or scientific instruments (Greenfield, 1995).

${ }^{3}$ Polonsky and Canat (1996) describe in detail the example of the proposed sale of The Three Graces in 1989. The expert advisor and Committee found that the piece fulfilled all three of the Waverley Criteria and so the licence was suspended initially for the standard period of six months. This was extended by another three months to try and let national museums raise the substantial asking price of $£ 7.6$ million, an offer which was extended to private sources in 1990. The application was withdrawn in 1990 but then a reapplication was put forth for the same proposed transaction in 1993 and a further six-month period of pre-emption upheld with a further and final extension of three months before the Victoria and Albert Museum finally secured the sale.

${ }^{4}$ In this particular case the sale to the Victoria and Albert Museum was only secured after a major fund-raising campaign. The final funds involved a large grant from the National Heritage Memorial fund, significant donations from J P Getty II and Baron Thyssen, £0.5 million from the National Arts Collections fund and $£ 0.1$ million in smaller-scale public and private donations (Casey et al, 1996).

${ }^{5}$ Defined in the survey as visual arts, crafts, art trade, museums and galleries and the national collections.

6 Other changes outlined in the paper included the exclusion of the dealers commission when considering setting a recommended 'fair market price' of a work under export deferral and the decision to continue to treat the works of living artists as any other goods (in other words the rejection of the Reviewing Committee's concerns that works of living artists should be subject to export control).

${ }^{7}$ These include National Museums, galleries, registered charities, trusts, local authorities, universities and various other government and non- government bodies.

${ }^{8}$ From the previous example, if the owner of the painting also had an additional tax liability of $£ 500,000$ due on the transfer of an estate, he may offer the painting in lieu which comes to a value of $£ 55,000(100,000-60,000+15,000)$, and so the owner now pays tax of $£ 500,000-£ 55,000=£ 445,000$ plus hands over the work instead of $£ 560,000$ without the exemptions. It should be noted that in this scheme the douceur is fixed at 25 per cent but this is not that meaningful as there can be considerable flexibility in determining market price.

${ }^{9}$ It is interesting to note that despite the similarity of the criteria, there are two separate-decision making bodies determining whether works qualify for export restriction (Reviewing Committee) versus tax incentives (Inland Revenue)

${ }^{10}$ An example given by Schuster (1986) is when $£ 5.5$ million was raised for Constable’s Stratford Mill which brought the total acceptances in lieu that year close to $£ 9$ million.

11 Specifically objects eligible for conditional exemption are: pictures, prints, books, manuscripts, works of art, scientific collections or other things not yielding income which appear to the commissioner of the Inland Revenue to be of national, scientific or artistic interest (Inland Revenue, 1986).

${ }^{12}$ As well as the fact that it could never bind for example the US or Japan who are major traders in the international art market and receivers of illicitly exported art works.

${ }^{13}$ A thorough article by article account and summary of drafting process is given in Prott and O'Keefe (1989)

14 For example, in relation to Article 7(a) preventing museums from acquiring stolen objects, the US interpreted this as applying only to those museum whose acquisition policies are subject to the control of the Federal government which formally exempts most museums, while other states interpretation was a more universal applicability. Bator (1981) describes parts of the convention text as "ceremonial, rhetorical and ineffective' and bar Articles 7 and 9 could be safely ignored as having no substantive effect. Although this criticism seems harsh, he does recognise that the processes of creating the 
convention were badly designed and run, which marred the final product, but recognises that ' behind this stands a conscientious and serious effort to make at least a moderate start at dealing with a set of baffling problems by narrowing and bridging genuine and legitimate differences in values.'( Bator, 1981, p. 100.) 
Table 1. Intra and Extra EU-destination Exports of Works of Art from the UK: Threshold Values and Age Limits for Licences Required

\begin{tabular}{|c|c|c|}
\hline Category of art & EU licence: & UK Licence \\
\hline $\begin{array}{l}\text { Architectural scientific and } \\
\text { engineering drawings> } 50 \mathrm{yrs}\end{array}$ & $£ 11,900$ & $£$ zero \\
\hline Archaeological material & $\begin{array}{l}\text { £zero and }>100 \\
\text { years }\end{array}$ & $\begin{array}{l}£ 39,600 \text { and }>50 \\
\text { years }\end{array}$ \\
\hline $\begin{array}{l}\text { Parts of historic, religious or artistic } \\
\text { monuments: }\end{array}$ & $\begin{array}{l}\text { £zero and }>50 \\
\text { years }\end{array}$ & $\begin{array}{l}£ 39,600 \text { and }>50 \\
\text { years }\end{array}$ \\
\hline $\begin{array}{l}\text { Portraits of British Historic Persons } \\
>50 \text { years }\end{array}$ & $£ 119,000$ & $£ 6,000$ \\
\hline Textiles $>50$ years & $£ 39,600$ & $£ 6,000$ \\
\hline Mosaics $>50$ years & $£ 11,900$ & $£ 39,600$ \\
\hline Drawings(by hand) $>50$ years & $£ 11,900$ & $£ 39,600$ \\
\hline $\begin{array}{l}\text { Original engravings, prints, and } \\
\text { posters }>50 \mathrm{yrs}\end{array}$ & $£ 11,900$ & $£ 39,600$ \\
\hline Original Sculptures $>50 \mathrm{yrs}$ & $£ 39,600$ & $£ 39,600$ \\
\hline $\begin{array}{l}\text { Pottery, glassware, silver, metal and } \\
\text { jewellery }>50 \mathrm{yrs}\end{array}$ & $£ 39,600$ & $£ 39,600$ \\
\hline Tapestries > 50 years & $£ 39,600$ & $£ 39,600$ \\
\hline $\begin{array}{l}\text { Paintings } \\
\text { a) water-colours, gouache, or pastel } \\
\text { b) oils or tempura }\end{array}$ & $\begin{array}{l}\text { a) } £ 23,800 \\
\text { b) } £ 119,00\end{array}$ & $\begin{array}{l}\text { a) } 39,600 \\
\text { b) } £ 119,00\end{array}$ \\
\hline $\begin{array}{l}\text { Collections of historical, } \\
\text { ethnographic, numismatic or } \\
\text { paleotological interest }>50 \text { years }\end{array}$ & $£ 39,600$ & $£ 39,600$ \\
\hline
\end{tabular}

Source: Christies (1998)

Note: UK licence needed for intra-community trade and for extra-community trade licence with lowest age and/or value thresholds applies. 
Table 2. Exports of Works of Art from the UK (1990-98)

\begin{tabular}{|l|l|l|l|l|l|}
\hline Year & $\begin{array}{l}\text { Value of } \\
\text { licensed } \\
\text { exports } \\
\text { (£ thous) }\end{array}$ & $\begin{array}{l}\text { Value of } \\
\text { unlicensed } \\
\text { exports } \\
\text { (£ thous) }\end{array}$ & $\begin{array}{l}\text { Volue of } \\
\text { works not } \\
\text { (£ thous)* }\end{array}$ & $\begin{array}{l}\text { Value of } \\
\text { total exports } \\
\text { (£ thous) }\end{array}$ & $\begin{array}{l}\text { unlicensed } \\
\text { exports } \\
\text { inTotal }\end{array}$ \\
\hline $1989-90$ & 16,653 & $2,223,524$ & 1,479 & $2,240,177$ & $99.25 \%$ \\
\hline $1990-91$ & 36,504 & $1,729,729$ & 3,265 & $1,766,233$ & $97.93 \%$ \\
\hline $1991-92$ & 25,986 & $1,608,547$ & 2,176 & $1,634,533$ & $98.41 \%$ \\
\hline $1992-93$ & 21,600 & $1,146,723$ & 861 & $1,168,323$ & $98.15 \%$ \\
\hline $1993-94$ & 17,867 & $1,329,204$ & 9,079 & $1,347,071$ & $98.67 \%$ \\
\hline $1994-95$ & 9,126 & $1,259,931$ & 9,368 & $1,269,057$ & $99.28 \%$ \\
\hline $1995-96$ & 22,287 & $1,275,857$ & 6,019 & $1,298,144$ & $98.28 \%$ \\
\hline $1996-97$ & 23,326 & $1,288,955$ & 1,556 & $1,312,281$ & $98.22 \%$ \\
\hline $1997-98$ & 18,896 & $2,745,508$ & 2,949 & $2,764,404 * *$ & $99.32 \%$ \\
\hline
\end{tabular}

Source: Reviewing Committee on the Export of Works of Art, Annual Reports (1993-94 and 1997-98)

* Cases considered by the Reviewing Committee, deferred and then not granted a licence.

** Figure for total exports taken from Eurostat (1988) (converted from euro at exchange rate 0.6509euro: 1GBP) 
Table 3. Applications for Licences Referred to the Reviewing Committee (199098)

\begin{tabular}{|l|l|l|l|l|l|l|}
\hline Year & $\begin{array}{l}\text { Total no. } \\
\text { of cases } \\
\text { considered }\end{array}$ & $\begin{array}{l}\text { No. of } \\
\text { works }\end{array}$ & $\begin{array}{l}\text { Total } \\
\text { value of } \\
\text { works } \\
\text { retained }\end{array}$ & $\begin{array}{l}\text { No. of } \\
\text { works }\end{array}$ & $\begin{array}{l}\text { Total value } \\
\text { of licensed }\end{array}$ & $\begin{array}{l}\text { Per cent } \\
\text { of }\end{array}$ \\
\hline $1989 / 90$ & 24 & 5 & $1,479,452$ & 10 & $16,653,839$ & $67 \%$ \\
\hline $1990 / 91$ & 27 & 10 & $3,365,705$ & 9 & $36,504,550$ & $47 \%$ \\
\hline $1991 / 92$ & 47 & 19 & $2,176,765$ & 23 & $25,985,761$ & $54 \%$ \\
\hline $1992 / 93$ & 20 & 7 & 861,108 & 8 & $21,600,011$ & $53 \%$ \\
\hline $1993 / 94$ & 24 & 7 & $9,079,800$ & 11 & $17,867,396$ & $61 \%$ \\
\hline $1994 / 95$ & 36 & 12 & $3,178,842$ & 12 & $9,126,154$ & $41 \%$ \\
\hline $1995 / 96$ & 27 & 14 & $6,019,125$ & 10 & $22,287,294$ & $42 \%$ \\
\hline $1996 / 97$ & 29 & 12 & $1,556,602$ & 14 & $23,326,737$ & $54 \%$ \\
\hline $1997 / 98$ & 19 & 7 & $2,949,300$ & 7 & $18,806,763$ & $47 \%$ \\
\hline
\end{tabular}

Source: Reviewing Committee on the Export of Works of Art, Annual Reports (VariousYears) 
Table 4. Taxes Satisfied by Acceptance in Lieu *

\begin{tabular}{|l|l|l|l|}
\hline Year & $\begin{array}{l}\text { Amount of tax satisfied by } \\
\text { acceptance in lieu }\end{array}$ & Year & $\begin{array}{l}\text { Amount of tax satisfied by } \\
\text { acceptance in lieu }\end{array}$ \\
\hline $1989 / 90$ & $£$ 11, 513, 768.05 & $1994 / 95$ & $£$ 6, 159, 616.00 \\
\hline $1990 / 91$ & $£$ 1, 251, 690.80 & $1995 / 96$ & $£$ 7, 406,959.00 \\
\hline $1991 / 92$ & $£ 3,340,445.72$ & $1996 / 97$ & $£ 2,170,758.90$ \\
\hline $1992 / 93$ & $£$ 6, 324, 875.13 & $1997 / 98$ & $£$ 6,785,070.00 \\
\hline $1993 / 94$ & $£ 3,114,660.00$ & $1998 / 99$ & $£ 25,299,384.00$ \\
\hline
\end{tabular}

Source: Department of Culture, Media and Sport (1999)

* It should be noted that these figures include all cultural items accepted in lieu. For example a stamp collection in 1990/91 (£113,00), Land $(£ 57,920)$ and Vintage Cars $(£ 153,000)$ in $1991 / 92$ or a harpsichord $(£ 10,500)$ and racing cup $(£ 15,400)$ etc. (Reviewing Committee on the Export of Works of Art). However by far the largest number of items in terms of quantity and value is paintings.

Table 5. Tax Losses due to Conditional Exemptions on Heritage Works*

\begin{tabular}{|l|l|l|l|}
\hline Year & $\begin{array}{l}\text { Tax losses due to } \\
\text { conditional } \\
\text { exemption (£ thous) }\end{array}$ & $\begin{array}{l}\text { Total inheritance } \\
\text { tax paid (£ thous) }\end{array}$ & $\begin{array}{l}\text { Per cent of } \\
\text { exemptions in total }\end{array}$ \\
\hline $1989 / 90$ & 183,400 & $1,232,000$ & $14.9 \%$ \\
\hline $1990 / 91$ & 21,600 & $1,262,000$ & $1.7 \%$ \\
\hline $1991 / 92$ & 44,400 & $1,299,000$ & $3.4 \%$ \\
\hline $1992 / 93$ & 80,400 & $1,211,000$ & $6.3 \%$ \\
\hline $1993 / 94$ & 136,800 & $1,333,000$ & $10.3 \%$ \\
\hline $1994 / 95$ & 30,800 & $1,411,000$ & $2.2 \%$ \\
\hline $1995 / 96$ & 42,500 & $1,518,000$ & $2.8 \%$ \\
\hline $1996 / 97$ & 30,100 & $1,558,000$ & $1.9 \%$ \\
\hline Source: & & & \\
\hline
\end{tabular}

Source: Inland Revenue Statistics (Various Years)

* Note: These figures include both conditionally exempt property and exempt transfers to national bodies 


\section{References}

Bailey, M. (1997) "Private Buyers of Export-stopped Works Must Allow Access to Them.". The Art Newspaper. vol. April , no. 69, pp. 7.

Bator, P. (1989) The International Trade in Art. Chicago: University of Chicago Press.

Biondi, A. (1997) "The Merchant, the Thief and the Citizen: the Circulation of Works of Art within the European Union." Common Market Law Review. Vol. 34, pp. 1173-1195.

Captial Taxes Office (1999) Capital Taxes - Relieffor Heritage Assets. London: Inland Revenue.

Casey, B. Dunlop, R. and Selwood, S. (1996) Culture as Commodity. London: Policy Studies Institute .

Christies (1998) Guide du Droit de l'Art. Geneva: Christies.

DCMS (1998) Annual Report of the Department of Culture, Media and Sport at http://www.culture.gov.uk/DCMSANN.HTM

DCMS (1999) Annual Report of the Department of Culture, Media and Sport at http://www.culture.gov.uk/DCMSANN.HTM

European Commission (1992) EEC Council Regulation No.3911/92 on the Export of Cultural Goods. Brussels: European Commission.

European Commission (1998) "Movement of Cultural Assets" from Report on the

Consideration of Cultural Aspects in the European Community" at http://europa.eu.int/en/comm/dg10/culture/cult-asp/en/index.htm

Giardina, E. and Rizzo, I. (1994) "Regulation in the Cultural Sector" in Peacock, A. and

Rizzo, I. (eds) (1994) Cultural Economics and Cultural Policies. Dordrecht : Kluwer Academic Publications.

Greenfield, J. (1995) The Return of Cultural Treasures (second edition). Cambridge:

Cambridge University Press.

Inland Revenue (1986) Capital Taxation and National Heritage. London: Board of the Inland Revenue.

Inland Revenue (1989-1998) Inland Revenue Statistics. London: HMSO.

Polonsky, M and Canat, J (1996) "The British and French Systems of Control of the Export of Works of Art." International and Comparative Law Quarterly. Vol. 5, pp. 557-591.

Prott, L. and O'Keefe, P. (1989) Law and the Cultural Heritage Volume Three: Movement. London : Butterworths.

Reviewing Committee on the Export of Works of Art. Annual Reports. London: HMSO.

Schuster, M. (1986) "Tax Incentives as Arts Policy in Western Europe" in Di Maggio, P. (ed.) (1986) Nonprofit Enterprise in the Arts. Oxford: Oxford University Press. 
Selwood, S. 1998 "Art and Antiques Trade." Cultural Trends. Vol. 29, pp. 37-69.

UNESCO (1989) Handbook of National Regulations Concerning the Export of Cultural Property. Paris : UNESCO. 